\title{
GAMBARAN TINGKAT PENGETAHUAN IBU NIFAS TENTANG PENCEGAHAN INFEKSI LUKA PERINEUM DI KLINIK KRISTINA SIDIKALANG TAHUN 2021
}

\author{
Ermawaty Arisandi Siallagan ${ }^{1}$, Febiola Elfrida Manurung ${ }^{2 *}$ \\ ${ }^{1,2}$ STIKes Santa Elisabeth, Medan, Indonesia \\ Email: rmaariezandie.marpaung@gmail.com ${ }^{1} *$
}

\begin{abstract}
Abstrak
Latar Belakang: Rupture adalah luka pada perineum yang diakibatkan oleh rusaknya jaringan secara alamiah karena proses desakan kepala janin atau bahu pada saat persalinan. Infeksi masa postpartum (puerpuralis) adalah infeksi pada genitalia setelah persalinan, ditandai dengan kenaikan suhu hingga mencapai $38^{\circ} \mathrm{C}$ atau lebih selama 2 hari dalam 10 hari pertama pasca persalinan dengan mengecualikan 24 jam pertama.Infeksi postpartum mencakup semua peradangan yang disebabkan oleh masuk kuman-kuman atau bakteri ke dalam alat genetalia pada waktu persalinan dan postpartum.

Tujuan : penelitian ini yaitu untuk mengetahui Gambaran Tingkat Pengetahuan Ibu nifas tentang Pencegahan Infeksi Luka Perineum Teknik sampel ini menggunakan Teknik Non Probability sampling yaitu metode Total sampling.Sampel dalam penelitian ini yaitu seluruh ibu nifas baik yang mengalami rupture dan yang tidak mengalami Di Klinik Kristina 2021 sebanyak 20 orang. Penelitian dilakukan dengan cara membagikan kuesioner kepada seluruh ibu nifas.

Hasil penelitian: yang diperoleh berdasarkan pengetahuan Ibu Nifas Tentang Pencegahan Infeksi Luka Perineum Berdasarkan Pendidikan, dapat di lihat dari mayoritas respoden memiliki pengetahuan yang baik dengan jumlah 11 orang $(55.0 \%)$ dan minoritas memiliki pengetahuan yang kurang dengan jumlah 7 orang $(35.0 \%)$.

Saran: Diharapkan bagi bidan agar dapat melakukan kunjungan nifas selama 6 minggu agar dapat memantau proses penyembuhan luka perineum pada pasien agar terhindar dari infeksi luka perineum dan memberikan selalu memberikan edukasi tentang bagaimana cara pencegahan infeksi luka perineum dan tanda dan bahaya luka perineum.
\end{abstract}

Kata kunci: Pengetahuan, Ibu nifas, Pencegahan Infeksi, Luka Perineum 


\begin{abstract}
Background:Rupture is an injury to the perineum caused by natural tissue damage due to pressure on the fetal head or shoulders during delivery. Postpartum infection (puerpuralis) is an infection of the genitalia after childbirth, which is characterized by an increase in temperature to $38^{\circ} \mathrm{C}$ or more for 2 days in the first 10 days after delivery, excluding the first 24 hours. Postpartum infection includes all inflammation caused by entry of germs. or bacteria into the genital tract at the time of delivery and postpartum.

Objective:The specific purpose of this study was to describe the level of knowledge of the mother about the prevention of perineal wound infection at the Kristina Clinic in 2021. This study used Non Probability Technique Sampling which is the total sampling method. The samples in this study were all postpartum mothers, both those who experienced rupture and those who did not at Kristina Clinic 2021, as many as 20 people. The research was conducted by distributing questionnaires to all postpartum mothers.

The results: obtained based on the knowledge of postpartum mothers about the prevention of perineal wound infection based on education, it can be seen from the majority of respondents having good knowledge with 11 people $(55.0 \%)$ and the minority having knowledge less with the number of 7 people $(35.0 \%)$.

Conclusion: It is hoped that midwives will be able to conduct postnatal visits for 6 weeks in order to monitor the healing process of perineal wounds in patients to avoid infection of perineal wounds and provide education on how to prevent perineal wound infections and the signs and dangers of perineal wounds.
\end{abstract}

Keywords: Knowledge, postpartum mothers, Infection Prevention, Perineal Wounds

\title{
Pendahuluan
}

Rupture adalah luka pada perineum yang diakibatkan oleh rusaknya jaringan secara alamiah karena proses desakan kepala janin atau bahu pada saat persalinan. Bentuk rupture biasanya tidak teratur sehingga jaringan yang robek sulit dilakukan penjahitan (Sukrisno, Adi 2010). Robekan perineum ini terjadi hampir setiap semua persalinan pertama dan tidak jarang juga pada persalinan selanjutnya.

Beberapa faktor penyebab terjadinya robekan perineum terdiri atas factor maternal, janin besar, posisi yang abnormal seperti oksipito posterior, presentasi muka, presentasi bokong, distosia bahu dan anomaly congenital seperti hidrosepalus. Faktor penolong meliputi dengan cara memimpin mengejan, cara berkomuikasi dan keterampilan menahan perineum. Faktor maternal meliputi primigravida, kelenturan perineum, odema perineum, kesempitan pintu bawah panggul, kelenturan jalan lahir mengejan terlalu kuat. Persalinan dengan tindakan seperti ekstrasivakum, ekstra siforce, versi ekstrasi pada pelvic maupun jaringan parut pada perineum dan vagina (Oxorn, 2010).

Kematian ibu di Indonesia salah satunya yaitu karena infeksi. Infeksi post partum yang salah satunya infeksi karena rupture perineum adalah penyebab kematian maternal yang merupakan urutan kedua setelah perdarahan jika tidak segera ditangani. Infeksi post partum terjadi di traktus genitalia setelah kelahiran yang diakibatkan oleh bakteri. Hal ini akan meningkatkan resiko infeksi post partum yang salah satunya disebabkan oleh luka perineum (Susilo Damarini, 2013). Faktor penyebab utama terjadinya infeksi pada masa nifas ialah adanya perlukaan pada perineum (Dwi Widiyastuti, 2016). 
Penyembuhan luka pada ibu pasca bersalin dipengaruhi oleh berbagai faktor diantaranya mobilisasi dini, nutrisi, dan perawatan perineum (kebersihan diri) (Anggraeni, 2010). Sedangkan infeksi jalan lahir dapat dicegah dengan perilaku hidup bersih dan sehat termasuk kebersihan diri dengan melakukan perawatan pada luka perineum, melakukan vulva hygiene yang benar. Infeksi nifas juga sering terjadi karena pengetahuan ibu nifas tentang perawatan luka perineum yang kurang baik seperti tidak mencuci luka perineum dengan air sabun, tidak mengeringkan genitalia setelah BAK dan BAB dan tidak melakukan cebok dari depan ke belakang akan menyebabkan infeksi perineum. Pengetahuan rendah atau kurang kemungkinan terjadi infeksi akan lebih besar karena kesalahan dalam perawatan luka perineum (Manuaba, 2009). Perawatan perineum yang tidak benar dapat mengakibatkan kondisi perineum yang terkena lokhea dan lembab akan sangat menunjang perkembangbiakan bakteri yang dapat menyebabkan timbulnya infeksi pada perineum. Munculnya infeksi pada perineum dapat merambat pada saluran kandung kencing ataupun pada jalan lahir yang dapat berakibat pada munculnya komplikasi infeksi kandung kencing maupun infeksi pada jalan lahir. Penanganan komplikasi yang lambat dapat menyebabkan terjadinya kematian ibu post partum mengingat kondisi ibu post partum masih lemah (Salmina, 2008).

Laporan Survey Demografi Kesehatan Indonesia (SDKI) tahun 2016 mengatakan bahwa angka kematian ibu di Indonesia mencapai 235 per 100.000 kelahiran hidup (Kemenkes). Angka tersebut di Negara-negara maju salah satunya disebabkan karena infeksi dengan proporsi 20-30\%, dan kasus ini 25-55\% disebabkan oleh infeksi jalan lahir, yang disebabkan beberapa faktor diantaranya kurangnya mobilisasi dini, vulva hygiene yang tidak benar, vaskulerisasi, stressor, dan juga nutrisi yang tidak seimbang (SDKI 2016).

Hal ini sejalan dengan hasil penelitian yang dilakukan oleh Siti et al (2012) di Semarang dapat dilihat ada beberapa faktor yang berhubungan dengan kejadian ruptur perineum antara lain umur 30 tahun berpotensi mengalami ruptur perineum pada saat bersalin. Prevelensi ibu bersalin yang mengalami ruptur perineum di Indonesia sebesar 52\% dikarenakan persalinan dengan bayi berat lahir cukup atau lebih (Fathus, 2013). Tujuan dari studi kasus ini adalah agar mahasiswa mampu memberikan Asuhan Kebidanan pada ibu Post Partum dengan Robekan Perineum Diharapkan ibu dan keluarga dapat melakukan upaya untuk mencegah terjadinya kemungkinan terburuk yang diakibatkan oleh robekan perineum dengan menjaga pola hidup sehat, personal hygiene, dan upaya pengecekkan secara rutin.

Hasil survey pendahuluan yang sudah dilakukan oleh peneliti pada Bulan November 2020 di Klinik Kristina dimana jumlah ibu bersalin ada 12 pasien bersalin dan yang mengalami rupture/laserasi ada 8 orang dan dari hasil wawancara pada ibu yang mengalami ruptur/laserasi perineum ada 5 orang yang tidak memahami bagaimana cara melakukan perawatan perineum yang merupakan suatu langkah untuk mencegah infeksi luka perineum. Berdasarkan uraian diatas maka peneliti tertarik untuk melakukan penelitian tentang "Gambaran Tingkat Pengetahuan Ibu Nifas Tentang Pencegahan Infeksi Luka Perineum di Klinik Kristina Di Sidikalang Tahun 2020.” 


\section{Metode Penelitian}

Metode penelitian ini bersifat deskriptif dengan menggunakan desain cross sectional. Variabel independent dan variabel dependent diteliti secara langsung dalam waktu bersamaan. Lokasi Penelitian di Klinik Kristina Sidikalang, Kecamatan Sidikalang, Kabupaten Dairi, Sumatera Utara. Populasi dalam penelitian ini semua ibu nifas yang bersalin yang mengalami luka perineum maupun yang tidak mengalami luka perineum di klinik Kristina Sidikalang. Sampel dalam penelitian ini adalah semua ibu nifas yang bersalin yang mengalami luka perineum maupun yang tidak mengalami luka perineum di klinik Kristina Sidikalang, teknik pengambilan sampel total sampling dengan jumlah sampel 20 orang.

\section{Hasil dan Pembahasan}

Hasil penelitian yang dilakukan pada bulan April 2021, diperoleh sebanyak 20 responden. Adapun hasil yang diperoleh sebagai berikut :

\subsubsection{Distribusi Pengetahuan Ibu Nifas tentang Pencegahan Infeksi Luka Perineum di Klinik Kristina Sidikalang Kabupaten Dairi Tahun 2021.}

Berdasarkan hasil penelitian,diperoleh data distribusi frekuensi pengetahuan ibu nifas tentang pencegahan infeksi.

Tabel 5.1 Distribusi Frekuensi Pengetahuan Ibu Nifas Tentang Pencegahan Infeksi Luka Perineum Di Klinik Kristina Sidikalang Kabupaten Dairi Tahun 2021.

\begin{tabular}{ccc}
\hline Pengetahuan & $\mathrm{f}$ & $(\%)$ \\
\hline Baik & 11 & 55.0 \\
Cukup & 2 & 10.0 \\
Kurang & 7 & 35.0 \\
\hline Jumlah & 20 & 100.0 \\
\hline
\end{tabular}

Dari tabel 5.1 untuk pengetahuan responden yang berpengetahuan baik sejumlah 11 orang (55\%), berpengetahuan cukup sejumlah 2 orang $(10.0 \%)$ dan yang berpengetahuan kurang 7 orang $(35.0 \%)$.

Tabel 5.2.2 Distribusi Frekuensi Karakteristik Responden tentang Tingkat Pengetahuan Ibu Nifas Tentang Pencegahan Infeksi Luka Perineum Berdasarkan Pendidikan, Pekerjaan, dan Usia di Klinik Kristina Sidikalang Kabupaten Dairi Tahun 2021.

\begin{tabular}{clcc}
\hline NO & \multicolumn{1}{c}{ Karakteristik } & f & $\%$ \\
\hline 1 & Pendidikan & 2 & 10 \\
& SD & 2 & 10 \\
& SMP & 7 & 35 \\
& SMA/SMK & 9 & 45 \\
\hline & PT & 20 & 100 \\
\hline & Jumlah & & \\
\hline
\end{tabular}




\begin{tabular}{llcc}
\hline & Petani & 5 & 25 \\
& PNS & 6 & 30 \\
& Wiraswasta & 6 & 30 \\
& DLL & 3 & 15 \\
& (Guru) & & \\
& Jumlah & & 100 \\
\hline \multirow{4}{*}{3} & Usia & 20 & \\
& $\leq 20$ & & 10 \\
& 20-35 Tahun & 2 & 75 \\
& $>35$ Tahun & 15 & 15 \\
\hline Jumlah & 3 & 100 \\
\hline 4 & Paritas & 20 & 50 \\
& Anak 1 & & 35 \\
& Anak 2 & 10 & 15 \\
\hline Anak $\geq 3$ & 7 & 100 \\
\hline
\end{tabular}

Tabel 5.2.2 menunjukkan bahwa berdasarkan tingkat pendidikan sebagian besar adalah Perguruan Tinggi sebanyak 9 orang atau $45 \%$. Berdasarkan pekerjaan sebagian besar bekerja sebagai,Wiraswata dan Pegawai Negeri Sipil sebanyak 6 orang atau 30\%. Berdasarkan usia sebagian besar berusia $20-35$ Tahun sebanyak 15 orang atau $75 \%$. Berdasarkan Paritas sebagian besar yaitu anak pertama yaitu 10 orang atau $50 \%$.

\subsubsection{Distribusi Pengetahuan Ibu Nifas Tentang Pencegahan Infeksi Luka Perineum Di Klinik Kristina Kecamatan Sidikalang Kabupaten Dairi Tahun 2021.}

Tabel 5.2.3 Distribusi Frekuensi Pengetahuan Ibu Nifas Berdasarkan Pendidikan Tentang Pencegahan Infeksi Luka Perineum Di Klinik Kristina Kecamatan Sidikalang Kabupaten Dairi Tahun 2021.

\begin{tabular}{ccccccccc}
\hline & \multicolumn{9}{c}{ Tingkat Pengetahuan } \\
\cline { 2 - 9 } Pendidikan & \multicolumn{2}{c}{ Baik } & \multicolumn{2}{c}{ Cukup } & \multicolumn{2}{c}{ Kurang } & \multicolumn{2}{c}{ Jumlah } \\
\cline { 2 - 9 } & $\mathrm{f}$ & $\%$ & $\mathrm{f}$ & $\%$ & $\mathrm{f}$ & $\%$ & $\mathrm{f}$ & $\%$ \\
\hline SD & 0 & 0,0 & 0 & 0,0 & 2 & 10 & 2 & 10 \\
SMP & 0 & 0,0 & 1 & 5 & 1 & 5 & 2 & 10 \\
SMA/SMK & 2 & 10 & 1 & 5 & 4 & 20 & 7 & 35 \\
PT & 9 & 45 & 0 & 0.0 & 0 & 0.0 & 9 & 45 \\
\hline Jumlah & 11 & 55 & 2 & 10 & 7 & 35 & 20 & 100 \\
\hline
\end{tabular}

Dari tabel 5.2.3 dapat dilihat bahwa gambaran pengetahuan ibu Tentang Pencegahan Infeksi Luka Perineum berdasarkan pendidikan SD berpengetahuan Kurang 2 orang (10\%). Pendidikan SMP berpengetahuan Cukup 1 orang (5\%) dan berpengetahuan kurang terdapat 1 orang $(10 \%)$. Pendidikan SMA berpengetahuan baik 2 orang $(10,0 \%)$, berpengetahuan cukup 1 orang $(5 \%)$ dan berpengetahuan kurang terdapat 4 orang $(20,0 \%)$. Pendidikan PT berpengetahuan baik 9 orang $(45 \%)$. 


\subsubsection{Distribusi Pengetahuan Ibu Nifas Tentang Pencegahan Infeksi Luka Perineum Di Klinik Krisitina Kecamatan Sidikalang Kabupaten Dairi Tahun 2021.}

Tabel 5.2.4 Distribusi Frekuensi Pengetahuan Ibu Nifas Berdasarkan Pekerjaan Tentang Pencegahan Infeksi Luka Perineum Di Klinik Kristina Kecamatan Sidikalang Kabupaten Dairi Tahun 2021.

\begin{tabular}{ccccccccc}
\hline & \multicolumn{8}{c}{ Tingkat Pengetahuan } \\
\cline { 2 - 10 } Pekerjaan & Baik & \multicolumn{3}{c}{ Cukup } & Kurang & \multicolumn{3}{c}{ Jumlah } \\
\cline { 2 - 10 } & $\mathrm{f}$ & $\%$ & $\mathrm{f}$ & $\%$ & $\mathrm{f}$ & $\%$ & $\mathrm{f}$ & $\%$ \\
\hline Petani & 1 & 5 & 0 & 0,0 & 4 & 20 & 5 & 25 \\
PNS & 6 & 30 & 0 & 0,0 & 0 & 0,0 & 6 & 30 \\
Wiraswata & 1 & 5 & 2 & 10 & 3 & 15 & 6 & 30 \\
DDL & 3 & 15 & 0 & 0,0 & 0 & 0,0 & 3 & 15 \\
(Guru, & & & & & & & & \\
\hline Jumlah & 11 & 55 & 2 & 10 & 7 & 35 & 20 & 100 \\
\hline
\end{tabular}

Dari tabel 5.2.4 dapat dilihat bahwa gambaran pengetahuan ibu Pencegahan Infeksi Luka Perineum berdasarkan pekerjaan sebagai Petani berpengetahuan baik 1 orang $(5,0 \%)$ dan berpengetahuan kurang 4 orang $(20,0 \%)$. Berdasarkan pekerjaan sebagai PNS yang berpengetahuan baik 6 orang $(30,0 \%)$ Berdasarkan pekerjaan sebagai wirausaha yang berpengetahuan baik 1 orang (5\%) dan berpengetahuan cukup 2 ( $10 \%$ ) dan berpengetahuan kurang orang kurang 3 orang $(15,0 \%)$ dan Berdasarkan pekerjaan sebagai Guru berpengetahuan baik 3 orang $(15 \%)$.

\subsubsection{Distribusi Pengetahuan Ibu Nifas tentang Pencegahan Infeksi Luka Perineum di Klinik Kristina Kecamatan Sidikalang Kabupaten Dairi Tahun 2021.}

Tabel 5.2.5 Distribusi Frekuensi Pengetahuan Ibu Nifas Berdasarkan Usia tentang Pencegahan Infeksi Luka Perineum di Klinik Kristina Kecamatan Sidikalang Kabupaten Dairi Tahun 2021.

\begin{tabular}{ccccccccc}
\hline & \multicolumn{8}{c}{ Tingkat Pengetahuan } \\
\cline { 2 - 10 } Usia & \multicolumn{2}{c}{ Baik } & \multicolumn{2}{c}{ Cukup } & \multicolumn{2}{c}{ Kurang } & \multicolumn{2}{c}{ Jumlah } \\
\cline { 2 - 10 } & $\mathrm{f}$ & $\%$ & $\mathrm{f}$ & $\%$ & $\mathrm{f}$ & $\%$ & $\mathrm{f}$ & $\%$ \\
\hline <20 Tahun & 0 & 0,0 & 1 & 5 & 1 & 5 & 2 & 10 \\
20-35 Tahun & 9 & 45 & 1 & 5 & 5 & 25 & 15 & 75 \\
$>35$ Tahun & 2 & 10 & 0 & 0.0 & 1 & 5 & 3 & 15 \\
\hline Jumlah & 11 & 55 & 2 & 10 & 7 & 35 & 20 & 100 \\
\hline
\end{tabular}

Dari tabel 5.2.5 dapat dilihat bahwa gambaran pengetahuan ibu Tentang Pencegahan Infeksi Luka Perineum berdasarkan usia $\leq 20$ Tahun ibu berpengetahuan cukup 1 orang (5\%) dan berpengetahuan kurang terdapat 1 orang (5\%). Dan 20-35 Tahun adalah ibu berpengetahuan baik 9 orang (45\%), berpengetahuan cukup 1 orang (5\%) dan berpengetahuan kurang terdapat 5 orang (25\%). Berdasarkan usia $>35$ Tahun berpengetahuan baik 2 orang $(10,0 \%)$, dan berpengetahuan kurang terdapat 1 orang $(5 \%)$. 


\subsubsection{Distribusi Pengetahuan Ibu Nifas tentang Pencegahan Infeksi Luka Perineum di Klinik Kristina Kecamatan Sidikalang Kabupaten Dairi Tahun 2021.}

Tabel 5.2.6 Distribusi Frekuensi Pengetahuan Ibu Nifas Berdasarkan Paritas tentang Pencegahan Infeksi Luka Perineum di Klinik Kristina Kecamatan Sidikalang Kabupaten Dairi Tahun 2021.

Tingkat Pengetahuan

\begin{tabular}{cccccccccc}
\cline { 2 - 8 } Paritas & \multicolumn{2}{c}{ Baik } & \multicolumn{2}{c}{ Cukup } & \multicolumn{2}{c}{ Kurang } & \multicolumn{2}{c}{ Jumlah } \\
\cline { 2 - 9 } & $\mathrm{f}$ & $\%$ & $\mathrm{f}$ & $\%$ & $\mathrm{f}$ & $\%$ & $\mathrm{f}$ & $\%$ \\
\hline Anak 1 & 3 & 15 & 2 & 10 & 5 & 25 & 10 & 50 \\
Anak 2 & 6 & 30 & 0 & 0,0 & 1 & 5 & 7 & 35 \\
Anak $\geq 3$ & 2 & 10 & 0 & 0,0 & 1 & 5 & 3 & 15 \\
\hline Jumlah & 11 & 55 & 2 & 10 & 7 & 35 & 20 & 100
\end{tabular}

Dari tabel 5.2.6 dapat dilihat bahwa gambaran pengetahuan ibu Tentang Pencegahan Infeksi Luka Perineum berdasarkan paritas anak 1 adalah ibu berpengetahuan baik 3 orang (15\%),dan berpengetahuan cukup ada 2 orang (10\%) berpengetahuan kurang 5 orang (25\%). Berdasarkan anak 2 berpengetahuan baik 2 6 orang $(30,0 \%)$, dan berpengetahuan Kurang terdapat 1 orang ( $5 \%$ ) Berdasarkan anak ke 3 berpengetahuan baik 2 orang (10,0\%), dan berpengetahuan kurang 1 orang $(5,0 \%)$.

\section{Pembahasan}

Setelah dilakukan penelitian mengenai Gambaran Tingkat Pengetahuan Ibu Nifas Tentang Pencegahan Infeksi Luka Perineum Di Kristina Sidikalang dengan 20 Responden, telah diperoleh hasil. Hasil tersebut akan dibahas dalam teori berikut :

\section{Gambaran Tingkat Pengetahuan Ibu Nifas tentang Pencegahan Infeksi Luka Perineum di Klinik Kristina Kecamatan Sidikalang Kabupaten Dairi Tahun 2021.}

Hasil penelitian yang dilakukan peneliti Tentang Pencegahan Infeksi Luka Perineum Di Klinik Kristina Kecamatan Sidikalang Kabupaten Dairi pengetahuan yang Baik sejumlah 11 orang (55\%), berpengetahuan yang cukup sejumlah 2 orang (10\%), dan berpengetahuan yang kurang 7 orang $(35 \%)$.

Hal ini sejalan dengan hasil penelitian oleh Kiki Indrayani Sagala "Pengetahuan Ibu Nifas Tentang Perawatan Luka Perineum Di Klinik Pratama Patumbak 2019" dimana hasil penelitian yang diperoleh dimana mayoritas respoden yang memiliki tingkat pengetahuan yang cukup sebanyak 20 orang $(52,6 \%)$ dan yang berpengetahuan kurang sebanyak 10 orang $(26,3 \%)$ dan pengetahuan baik 8 orang $(21,1)$.

Infeksi masa postpartum (puerpuralis) adalah infeksi pada genitalia setelah persalinan, ditandai dengan kenaikan suhu hingga mencapai $38^{\circ} \mathrm{C}$ atau lebih selama 2 hari dalam 10 hari pertama pasca persalinan dengan mengecualikan 24 jam pertama (Mitayani, 2011). Infeksi postpartum dapat disebabkan oleh adanya alat yang tidak steril, luka robekan jalan lahir, perdarahan, preeklamsia, dan kebersihan daerah perineum yang kurang terjaga. Infeksi masa postpartum dapat terjadi karena beberapa faktor pemungkin, antara lain pengetahuan yang kurang, gizi, pendidikan, dan usia. 
Natoatmodjo (2010) merupakan hasil tahu yang terjadi melalui proses sensoris khususnya matadan telinga terhadap suatu objek tertentu. Pengetahuan merupakan dominan yang sangat penting untuk terbentuknya perilaku seseorang. Tingkat pengetahuan yang di ukur dalam penelitian kali ini adalah pengetahuan tentang Pencegahan Infeksi Pada Luka Perineum.

Menurut asumsi peneliti bahwa sebagian responden memiliki pengetahuan yang baik, hal ini juga dipengaruhi oleh pendidikan dimana semakin tingginya pendidikan seseorang, maka pengetahuan juga akan semakin luas dan semakin mudah menerima informasi dan ide-ide dari orang lain. Sebaliknya bila ibu memiliki latar belakang pendidikan yang rendah pada umumnya mengalami kesulitan untuk menerima informasi baik dari media bahkan dari si bidan karna mereka menganggap sepele dan wawasan nya kurang tentang pencegahan infeksi luka perineum.

\section{Gambaran Karakteristik Pendidikan,Pekerjaan,Usia dan Paritas, Ibu Nifas Tentang Pencegahan Infeksi Luka Perineum di klinik Kristina tahun 2021}

Berdasarkan hasil penelitian distribusi responden berdasarkan pendidikan adalah sebagai berikut, yaitu 20 responden terdapat responden berpendidikan SD sebanyak 2 orang (10\%), SMP sebanyak 2 orang (10\%), SMA sebanyak 7 orang (35\%), dan perguruan tinggi sebanyak 9 orang ( $45 \%)$

Menurut Notoadmojo (2010), pendidikan dapat mempengaruhi seseorang termasuk juga perilaku seseorang akan pola hidup terutama dalam memotivasi untuk sikap berperan serta dalam pembangunan dan pada umumnya makin tinggi pendidikan seseorang makin mudah menerima informasi. Informasi tentang pencegahan infeksi luka perineum dapat diperoleh melalui media massa (surat kabar, majalah, televisi, radio, dan internet, keluarga, teman atau tetangga, serta dokter atau bidan.).

Menurut asumsi peneliti bahwa pendidikan juga sangat berpengaruh pada pengetahuan seseorang. Dimana semakin tinggi pendidikan maka akan semakin tinggi juga wawasan atau luas pula pengetahuannya. Begitu pula sebaliknya bila ibu yang memiliki latar belakang pendidikan yang rendah pada umumnya mengalami kesulitan dalam menerima informasi baik dari media atau pun tenaga kesehatan dikarnakan wawasan dan daya tangkapnya masih sangat minim.

Berdasarkan hasil penelitian dari 20 responden mengenai pekerjaan sebagai Petani ada 5 orang ( 25\%), PNS ada 6 orang (30\%), Wiraswasta ada 6 orang (30\%), dan guru ada 3 orang $(15 \%)$.

Menurut penelitian terdahulu (Yellita \& Darnisa, 2014) yaitu semakin tinggi pendapatan seseorang maka akan mudah seseorang mendapatkan informasi yang diperlukan, untuk mendapatkan informasi selain dari faktor pekerjaan ada faktor lain yang mempengaruhi yaitu faktor lokasi pekerjaan.

Menurut asumsi peneliti bahwa pekerjaan mempengaruhi tingkat pengetahuan seseorang. Dimana ibu yang bekerja akan kurang meluangkan waktunya dalam memperoleh informasi baik dari media social ataupun dari teman atau tenaga kesehatan. Begitu pula sebaliknya pada ibu yang tidak bekerja akan lebih banyak meluangkan waktunya dalam memperoleh informasi baik dari media social maupun teman dan tenaga kesehatan. 
Berdasarkan hasil penelitian dari 20 responden mengenai usia yaitu dari 20 responden yang berumur $\leq 20$ ada 2 orang (10\%), berumur $20-35$ tahun ada 15 orang (75\%), berumur $\geq 35$ tahun ada 3 orang $(15 \%)$.

Dari penelitian yang didapat oleh( Intan Silviana, 2014) bahwa usia antara 25-35 Tahun dimana usia tersebut masuk ke dalam usia produktif dimana dalam usia tersebut termasuk ke tahap dewasa awal merupakan puncak dari kondisi fisik yang sangat prima. Jadi, usia berpengaruh dengan daya ingat dan pola pikir seseorang. Hal ini dimana usia mempengaruhi daya tangkap dan pola pikir seseorang. Semakin bertambah usia akan semakin berkembang pula daya tangkap dan pola pikirnya, sehingga pengetahuan yang diperoleh semakin membaik (Notoatmodjo, 2010). Selain itu semakin bertambahnya usia seseorang maka makin bertambah pula tingkat pengetahuan seseorang, seiring dengan pengalamanan hidup, emosi, pengetahuan, dan keyakinan yang lebih matang. Akan tetapi pada usia tertentu bertambahnya proses perkembangan mental ini tidak secepat seperti ketika berusia belasan tahun.

Menurut asumsi peneliti bahwa usia juga mempengaruhi pengetahuan dalam pola pikir dan daya tangkap seseorang dikarnakan semakin dewasa usia seseorang maka semakin meningkat pengetahuan dan wawasan seseorang dan dikarnakan pengalaman yang lebih banyak begitu juga daya ingat.

Berdasarkan hasil penelitian distribusi responden berdasarkan paritas yaitu dari 20 responden yang anak 1 ada 10 orang (50\%), Berdasarkan anak 2 ada 7 orang (35\%), Berdasarkan anak ke 3 ada 3 orang (15\%).

Menurut (Lailiyah, Tarmi, \& Wati, 2011) faktor pengalaman melahirkan dapat berpengaruh pada perawatan luka perineum yaitu dari faktor pengalamannya pada masa nifas yang lalu. Maka jumlah anak sangat berpengaruh dalam memperoleh pengalamannya tentang nifas, terutama pada perawatan luka perineum.Berdasarkan penelitian yang dilakukan oleh (Esti Nugraheny, 2016). Berdasarkan hasil penelitian diketahui terdapat 38 orang $(73,1 \%)$ yang mengalami riwayat persalinan dengan perlukaan perineum. Penelitian ini menunjukkan adanya pengaruh antara riwayat perlukaan perineum dengan kejadian ruptur perineum berdasarkan analisis deskriptif.

Menurut Asumsi peneliti bahwa ibu bersalin yang berparitas akan mempengaruhi tingkat pengetahuannya dimana pengalaman- pengalaman sebelumnya yang dimana semakin banyak pengalaman maka semakin banyak juga pengetahuannya.

\section{Gambaran Pengetahuan Ibu Nifas tentang Pencegahan Infeksi Luka Perineum Berdasarkan Pendidikan}

Berdasarkan hasil penelitian bahwa gambaran pengetahuan ibu Tentang Pencegahan Infeksi Luka Perineum berdasarkan pendidikan SD berpengetahuan Kurang 2 orang (10\%). Pendidikan SMP berpengetahuan Cukup 1 orang (5\%) dan berpengetahuan kurang terdapat 1 orang (10\%). Pendidikan SMA berpengetahuan baik 2 orang (10,0\%), berpengetahuan cukup 1 orang $(5 \%)$ dan berpengetahuan kurang terdapat 4 orang $(20,0 \%)$. Pendidikan PT berpengetahuan baik 9 orang $(45 \%)$.

Pendidikan merupakan salah satu usaha sadar yang dilakukan untuk meningkatkan sumber daya manusia. Sejak dilahirkan ke dunia, hampir setiap manusia dikenalkan dengan pendidikan meski dalam bentuk sederhana oleh orang tua masingmasing dan melaksanakan pendidikan hingga akhir hayat. Pendidikan dapat dikatakan sebagai khas milik dan alat manusia, tidak ada makhluk lain yang

memerlukan pendidikan selain manusia. 
Tujuan pendidikan yaitu: (1) mengubah pengetahuan atau pengertian, pendapat dan konsep-konsep; (2) mengubah sikap dan persepsi; (3) menanamkan tingkah laku atau kebiasaan yang baru (Maryono, 2011). Menurut Notoadmojo (2010), pendidikan dapat mempengaruhi seseorang termasuk juga perilaku seseorang akan pola hidup terutama dalam memotivasi untuk sikap berperan serta dalam pembangunan dan pada umumnya makin tinggi pendidikan seseorang makin mudah menerima informasi. Informasi tentang pencegahan infeksi luka perineum dapat diperoleh melalui media massa (surat kabar, majalah, televisi, radio, dan internet, keluarga, teman atau tetangga, serta dokter atau bidan.)

Menurut asumsi peneliti bahwa pendidikan juga sangat berpengaruh pada pengetahuan seseorang. Dimana semakin tinggi pendidikan maka akan semakin tinggi juga wawasan atau luas pula pengetahuannya. Begitu pula sebaliknya bila ibu yang memiliki latar belakang pendidikan yang rendah pada umumnya mengalami kesulitan dalam menerima informasi baik dari media atau pun tenaga kesehatan dikarnakan wawasan dan daya tangkapnya masih sangat minim.

\section{Gambaran Pengetahuan Ibu Nifas tentang Pencegahan Infeksi Luka Perineum Berdasarkan Pekerjaan}

Berdasarkan hasil penelitian bahwa gambaran pengetahuan ibu Pencegahan Infeksi Luka Perineum berdasarkan pekerjaan sebagai Petani berpengetahuan baik 1 orang $(5,0 \%)$ dan berpengetahuan kurang 4 orang $(20,0 \%)$. Berdasarkan pekerjaan sebagai PNS yang berpengetahuan baik 6 orang $(30,0 \%)$ Berdasarkan pekerjaan sebagai wirausaha yang berpengetahuan baik 1 orang (5\%) dan berpengetahuan cukup 2 orang (10\%) dan cukup 2 orang $(10 \%)$ dan pengetahuan kurang 3 orang $(15,0 \%)$ dan Berdasarkan pekerjaan sebagai Guru berpengetahuan baik 3 orang $(15 \%)$.

Menurut penelitian terdahulu (Yellita \& Darnisa, 2014) yaitu semakin tinggi pendapatan seseorang maka akan mudah seseorang mendapatkan informasi yang diperlukan, untuk mendapatkan informasi selain dari faktor pekerjaan ada faktor lain yang mempengaruhi yaitu faktor lokasi pekerjaan.

Semakin dekat lokasi pekerjaan dengan sumber informasi baik media cetak atau elektronik, maka semakin cepat dan banyak informasi yang diterima seseorang. Selain itu responden yang bekerja dapat memenuhi sarana prasarana untuk melakukan perawatan perineum diantaranya dapat membeli pembalut atau datang ke tempat pelayanan kesehatan, sedangkan untuk responden yang mengalami penyembuhan secara sedang terjadi karena mereka tidak mempunyai biaya yang cukup untuk dapat membeli atau menyediakan sarana prasarana yang dibutuhkan selama masa nifas terutama untuk penyembuhan luka perineum.Menurut (Mubarak, 2008), dengan bekerja seseorang dapat berbuat yang bernilai, bermanfaat dan memperoleh berbagai pengalaman. Selain itu, pekerjaan juga mempengaruhi daya beli seseorang, sehingga mampu memperoleh sumber informasi yang lebih banyak untuk menambah wawasan dan pengetahuan. Pekerjaan bukanlah sumber kesenangan, tetapi lebih banyak merupakan cara mencari nafkah yang membosankan, berulang dan banyak tantangan.

Menurut asumsi peneliti bahwa pekerjaan mempengaruhi tingkat pengetahuan seseorang. Dimana ibu yang bekerja akan kurang meluangkan waktunya dalam memperoleh informasi baik dari media social ataupun dari teman atau tenaga kesehatan. Begitu pula sebaliknya pada ibu yang tidak bekerja akan lebih banyak meluangkan waktunya dalam memperoleh informasi baik dari media social maupun teman dan tenaga kesehatan. 


\section{Gambaran Pengetahuan Ibu Tentang tentang Pencegahan Infeksi Luka Perineum Berdasarkan Usia}

Berdasarkan hasil penelitian bahwa gambaran pengetahuan ibu Tentang Pencegahan Infeksi Luka Perineum berdasarkan usia $\leq 20$ Tahun ibu berpengetahuan cukup 1 orang $(5 \%)$ dan berpengetahuan kurang terdapat 1 orang (5\%). Dan 20-35 Tahun adalah ibu berpengetahuan baik 9 orang (45\%), berpengetahuan cukup 1 orang (5\%) dan berpengetahuan kurang terdapat 5 orang (25\%). Berdasarkan usia $>35$ Tahun berpengetahuan baik 2 orang $(10,0 \%)$, dan berpengetahuan kurang terdapat 1 orang (5\%).

Hal ini sesuai dengan teori (Mubarak, 2010) yang mengatakan bahwa umur yang baik untuk nifas adalah umur 20-35 tahun, karena umur tersebut merupakan masa yang aman untuk nifas. Umur 20 tahun rahim dan bagian-bagian tubuh lainnya sudah benarbenar siap untuk menerima kehamilan dan pada umur tersebut wanita sudah dewasa dan siap untuk menjadi ibu dan umur 35 tahun merupakan umur resiko untuk reproduksi.

Hal ini sesuai dengan teori (Soehardjo, 2006) yang mengatakan bahwa semakin cukup umur tingkat kematangan dan kekuatan seseorang akan lebih matang dalam berpikir dan bekerja, sehingga semakin tinggi umur ibu semakin tinggi pula pengetahuannya. Ibu dengan umur yang terlalu muda akan memiliki pengalaman dan pengetahuan yang kurang.

Dari penelitian yang didapat oleh( Intan Silviana, 2014) bahwa usia antara 25-35 Tahun dimana usia tersebut masuk ke dalam usia produktif dimana dalam usia tersebut termasuk ke tahap dewasa awal merupakan puncak dari kondisi fisik yang sangat prima. Jadi, usia berpengaruh dengan daya ingat dan pola pikir seseorang. Hal ini dimana usia mempengaruhi daya tangkap dan pola pikir seseorang. Semakin bertambah usia akan semakin berkembang pula daya tangkap dan pola pikirnya, sehingga pengetahuan yang diperoleh semakin membaik (Notoatmodjo, 2010). Selain itu semakin bertambahnya usia seseorang maka makin bertambah pula tingkat pengetahuan seseorang, seiring dengan pengalamanan hidup, emosi, pengetahuan, dan keyakinan yang lebih matang. Akan tetapi pada usia tertentu bertambahnya proses perkembangan mental ini tidak secepat seperti ketika berusia belasan tahun.

Menurut asumsi peneliti bahwa usia juga mempengaruhi pengetahuan dalam pola pikir dan daya tangkap seseorang dikarnakan semakin dewasa usia seseorang maka semakin meningkat pengetahuan dan wawasan seseorang dan dikarnakan pengalaman yang lebih banyak begitu juga daya ingat.

\section{Gambaran Pengetahuan Ibu tentang Pencegahan Infeksi Luka Perineum Berdasarkan Paritas.}

Berdasarkan hasil penelitian bahwa gambaran pengetahuan ibu Tentang Pencegahan Infeksi Luka Perineum berdasarkan paritas anak 1 adalah ibu berpengetahuan baik 3 orang (15\%),dan berpengetahuan cukup ada 2 orang (10\%) berpengetahuan kurang 5 orang (25\%). Berdasarkan anak 2 berpengetahuan baik 26 orang $(30,0 \%)$, dan berpengetahuan Kurang terdapat 1 orang ( $5 \%)$. Berdasarkan anak ke 3 berpengetahuan baik 2 orang $(10,0 \%)$,dan berpengetahuan kurang 1 orang $(5,0 \%)$.

Menurut (Lailiyah, Tarmi, \& Wati, 2011) faktor pengalaman melahirkan dapat berpengaruh pada perawatan luka perineum yaitu dari faktor pengalamannya pada masa nifas yang lalu. Maka jumlah anak sangat berpengaruh dalam memperoleh pengalamannya tentang nifas, terutama pada perawatan luka perineum.Berdasarkan penelitian yang dilakukan oleh (Esti Nugraheny, 2016). Berdasarkan hasil penelitian diketahui terdapat 38 orang $(73,1 \%)$ yang mengalami riwayat persalinan dengan 
perlukaan perineum. Penelitian ini menunjukkan adanya pengaruh antara riwayat perlukaan perineum dengan kejadian ruptur perineum berdasarkan analisis deskriptif.

Menurut Asumsi peneliti bahwa ibu bersalin yang berparitas akan mempengaruhi tingkat pengetahuannya dimana pengalaman- pengalaman sebelumnya yang dimana semakin banyak pengalaman maka semakin banyak juga pengetahuannya.

\section{Kesimpulan}

Dari hasil penelitian yang telah dilakukan terhadap Ibu Nifas tentang pencegahan infeksi luka perineum di Klinik Kristina Sidikalang tahun 2021 dapat diambil kesimpulan sebagai berikut:

a. Gambaran Pengetahuan Ibu Nifas tentang Pencegahan Infeksi Luka Perineum mayoritas respoden memiliki pengetahuan yang baik dengan jumlah 11 orang

b. Gambaran Pengetahuan Ibu Nifas tentang Pencegahan Infeksi Luka Perineum Berdasarkan Karakteristik dapat di lihat dari mayoritas respoden memiliki pendidikan Perguruan Tinggi dengan jumlah 9 orang, pekerja sebagai Pegawai Negeri Sipil, usia mayoritas respoden berusia 20-35 Tahun, paritas mayoritas anak pertama ada 10 orang

c. Gambaran Pengetahuan Ibu Nifas tentang Pencegahan Infeksi Luka Perineum Berdasarkan Pendidikan mayoritas berpengetahuan baik 9 orang adalah pendidikan yang di Perguruan Tinggi.

d. Gambaran Pengetahuan Ibu Nifas tentang Pencegahan Infeksi Luka Perineum Berdasarkan pekerjaan sebagai PNS yang memiliki respoden mayoritas berpengetahuan baik 6 orang $(30,0 \%)$.

e. Gambaran Pengetahuan Ibu Nifas tentang Pencegahan Infeksi Luka Perineum Berdasarkan usia, dimana usia 20-35 Tahun adalah mayoritas respoden yang memiliki paling banyak berpengetahuan baik 9 orang (45\%).

f. Gambaran Pengetahuan Ibu Nifas tentang Pencegahan Infeksi Luka Perineum Berdasarkan paritas dimana responden yang memiliki anak 2 mayoritas berpengetahuan baik sebanyak 6 orang $(30,0 \%)$.

\section{Referensi}

Andhini, N. F. (2017). AKI dan AKB. Journal of Chemical Information and Modeling, 53(9), 1689-1699.

Badan Pusat Statistik, Badan Koordinasi Keluarga Berencanan Nasional, Departemen Kesehatan, Macro International. Survei Demografi dan Kesehatan Indonesia 2012. SDKI. 2013;16.

Damarini Susilo,( 2013) Efektifitas Sirih Merah dalam Perawatan Luka Perineum di Bidan Praktik Mandiri, Kesmas, Jurnal Kesehatan Masyarakat Nasional Vol. 8, No. 1.

Darmawati 2012. Hubungan Tingkat Pengetahuan dan Sikap Ibu Dengan Perawatan Luka Episiotomi Post Partum di RSIA. ;III(3):50-6 Departemen Kesehatan RI. 2015. Pedoman Kesehatan Maternal dan Neonatal.Jakarta (https://www.drugs.com/cg/postpartum-perineal-care-aftercare-instructions.html)

Darmawati, \& Fajria, N. (2012). Hubungan Tingkat Pengetahuan Dan Sikap Ibu Dengan Perawatan Luka Episiotomi Post Partum Di Rsia Correlation between Knowledge Level and Mother's Attitude with Post partum Episiotomy Wound Care in Mother and Child Hospital. Idea Nursing Journal, 3(3), 50-56. 
Departemen, RI. Kesehatan. (2016). Buku Profil Kesehatan 2016

Dinas Kesehatan Provinsi DIY. Yogyakarta: DINKES DIY. Depkes, R. (2016). Angka Kematian Ibu. Jakarta: Kementrian Dinas Kesehatan RI. Dinkes. (2016). Profil Kesehatan Daerah Istimewa Yogyakarta. Yogyakarta: DINKES DIY

Depkes RI. 2018 Inilah Capaian Kinerja Kemenkes RI Tahun 2015- 2017 [Internet].Jakarta;.Availablefrom:http://www.depkes.go.id/Article/View/1708170 0004/-Inilah-Capaian-KinerjaKemenkes-Ri-Tahun-2015-2017.

Dewi avia viva., Yuanita (2020) Buku AjarAsihan Kebidanan 3.

Elisa, Endah SN, Yumiarti S. Hubungan Paritas dengan Terjadinya Robekan Perineum Spontan pada Persalinan Normal. 2016;2(02):20-30.

Fatimah, \& Nuryaningsih. (2018). Buku Ajar Asuhan Kebidanan Griya Husada Surabaya.

Hidayah, S. N. (2017). Hubungan Antara Vulva Hygiene Dengan Lama Penyembuhan Luka Perineum Di Bps Ny S Desa Grobog Wetan Kecamatan Pangkah Kabupaten Tegal Tahun 2015. Siklus: Journal Research Midwifery Politeknik Tegal, 6(1), 188-194. https://doi.org/10.30591/siklus.v6i1. Nifas. Akademi Kebidanan $\underline{470}$

Kematian, A. A., Demografi, S., (2018)Indonesia, K., Ibu, A. K., Hidup, K., Making, U., Safer, P., Sei, I. I. I., Penelitian, H., \& Kunci, K. Jurnal Kebidanan-ISSN 2252$8121223.8,223-230$.

Ii, B. A. B. (2013). Faktor yang mempengaruhi penyembuhan luka perineum.

Octaviani, C. Valentine Ayu. 2012. Tingkat Pengetahuan Ibu Nifas. Tentang Infeksi Luka Perineum di RSU Assalam Gemolong Sragen. Sragen: Sekolah Tinggi Ilmu Kesehatan Kusuma Husada

Patriani.,Risa..dan Andriayani.,Rika Oktober $2014 \quad$-Ed 1,Yogyakarta Deepublishi,Panduan lengkap asuhan kebidanan ibu nifas normal (Askeb III)

Rustiana Ernik. (2020). Hubungan Pengetahuan Dengan Sikap Ibu. Jurnal Ilmiah Kesehatan Karya Putra Bangsa, 2(1), 39-43.

Safriana, R., Mulyani, E., \& Endah Rachmawati, A. (2019). Identification of The Puerperium Infection Characteristics. Jurnal Kebidanan, 9(1), 127-134. http://jurnal.unimus.ac.id/index.php/jur_bid/article/view/815/868

Sugiyono, P. D. (2016). Rupture Perineum. Journal of Chemical Information and Modeling, 53(9), 1689-1699.

Susiana, S. (2019). Angka Kematian Ibu : Faktor Penyebab Dan Upaya Penanganannya.

Suwardi, S., \& Mouliza, N. (2019). Hubungan Pengetahuan Ibu Menyusui Tentang Cara Perawatan Luka Perineum Dengan Infeksi Perineum Article history: Public Health Faculty Received in revised form 08 October 2019 Universitas Muslim Indonesia Accepted 09 October 2019 Address : Available Email. Window of Health : Jurnal Kesehatan, 2(4), 338-344.

Timbawa S, Kundre R, Bataha Y (2015). Hubungan Vulva Hygiene Dengan Pencegahan Infeksi Luka Perineum Pada Ibu Post Partum DiRumah Sakit Pancaran Kasih Gmim Manado.e-Journal Keperawatan (eKp).2015;3:26.TimelineofPostpartumRecovery.Healthline.(https://www.healthline.com/health/ postpartum-recovery-timeline

Tukan, P. P. (2014). Gambaran Tingkat Pengetahuan Ibu Nifas Tentang Perawatan Luka Perineum Di Puskesmas Depok III.

Tridiyawati F., Santika N. 2017. Hubungan Pengetahuan Ibu Nifas Terhadap Perawatan Luka Perineum. Jurnal Antara Kebidanan. http://ojs.abdinusantara.ac.id/index.php/antarakebidanan/article/view/37. Diakses tanggal 28 Mei 2019 
Vagina changes after childbirth. NHS (National Health Service). (https://www.nhs.uk/live-well/sexual-health/vagina-changes-after-childbirth/

Widia L (2017;). Hubungan Berat Lahir Bayi dengan Kejadian Ruptur Perineum pada Persalinan Hubungan Antara Paritas dengan kejadian Rupture Perineum.

Widyastuti, D. (2016) . Gambaran Sikap Ibu Nifas Tentang Perawatan.

Luka Perineum Di RSUD Wonosari Gunung Kidul. Skripsi.Yogyakarta: Universitas Alma Ata Yogyakarta

Wiknjosastro, H. (2008). Ilmu Kandungan. Jakarta: Yayasan Bina Pustaka Sarwono Prawirahardjo.

WHO. (2015). Maternal Mortality. (sumber online) Available at : http://www.who.int/mediacenter/factssheet/fs363/end. Accessed at 15 November 2018

World Health Organization, (WHO). (2015). Retrieved Desember 15, 2018, from WHO, UNICEF, UNFPA, The World Health Organization

Bank. Trends in Maternal mortality 1990 to 2015.

Wulandari, S. H. (2011). Asuhan Kebidanan Ibu Masa Nifas. Yogyakarta: Gosyen Publising.

Yanti, S. D. (2011). Asuhan Kebidanan Masa Nifas. Bandung: Refika Aditama 